Journal of Economics and Behavioral Studies

Vol. 6, No. 1, pp. 32-36, Jan 2014 (ISSN: 2220-6140)

\title{
Returns to Education and Earning Inequality Nexus: A Micro-Econometric Analysis for Pakistan
}

\author{
${ }^{1}$ Ghulam Sarwar", ${ }^{1}$ Maqbool Hussain Sial, ${ }^{2}$ Muhammad Saeed Hashmi \\ ${ }^{1}$ University of Sargodha, Pakistan \\ ${ }^{2}$ Lahore Leads University, Lahore, Pakistan \\ *sarwar41ss@hotmail.com
}

\begin{abstract}
This study investigates nexus between returns to education and earning inequality in Pakistan. The study utilizes quantile regression method to demonstrate how effect of different levels of education varies across conditional earning distribution. The results show that education plays a significant role in determination of within group earning inequality at all levels of education. Within group earning inequality is higher within the individuals having tertiary education as compared to the individuals having secondary and primary education. The earning inequality does not remain constant within the education groups during 2005-07. Moreover, education also causes earning inequality between educational groups. The findings of the study reveal that education has a positive effect on within as well as between groups earning inequality.
\end{abstract}

Keywords: Returns to education, earnings distribution, quantile regression, labor market, inequality

\section{Introduction}

Distribution of earnings has long been an area of interest among the economists. Initially, concentration was focused on relationship between earnings inequality and economic development. The most important idea on this relationship was established by Kuznets (1955). Since the work of Kuznets, there has been an interest in understanding the determinants of distribution of earnings. The current literature on inequality underlines education as a contributing factor towards earning inequality ${ }^{1}$. Human capital model illustrates that level and distribution of education determines earning distribution of a society (Becker, 1993). The contemporary research on returns to education has exposed that there exists a relationship between returns to education and earnings inequality (e.g. Buchinsky, 1994; Machado \& Mata, 2001; Fersterer \& Winter-Ebmer, 2003). They have taken into account the heterogeneity in earnings due to education. To provide the evidence on whether education is a contributing factor towards earning inequality or not, they provide a distributional analysis of earnings of educated workers. In doing so, they utilize quantile regression to understand that whether returns to education for individuals at upper tail of earning distribution are different from returns to education for those who are at lower tail of earning distribution with same level of education. If there is a difference then it is concluded that earning inequality is present due to education. The presence of such differences in returns to education has obvious implications for the labor market.

This study offers an empirical assessment of the relationship between returns to education and earning inequality in Pakistan. The present study contributes to the existing literature on earning inequality by analyzing the returns to different levels of education as a source of earning inequality. To this end, earning distribution is characterized by using two methods namely ordinary least squares (OLS) and quantile regression methods. OLS method assumes that the marginal effect of education on earnings is constant over the earning distribution. Therefore, the effect of an extra year of education can be represented by a right word shift of the conditional earning distribution. On other hand, quantile regression method measures effect of education on earnings at different parts of the distribution. As a result, it can describe changes not only in the location but also in the shape of the earning distribution. By combining the two methods, we attempt to measure the effect of education on earnings inequality within and between groups. That is, OLS returns measure the differences between educational groups, while differences in quantile returns show the earning differences between individuals having the same level of education but are located at different quantile. The

\footnotetext{
${ }^{1}$ See for example Gregorio and Lee (2002); Sylwester (2002); Checchi (2003).
} 
layout of study is as follows: a brief review of literature is provided in section 2 and methodology and the empirical specification of earning function based on quantile regression is presented in section 3 . Results and discussion are given in section 4 . Finally in section 5, concluding remarks are provided.

\section{Literature Review}

The most referred study in context of quantile regression is Machado and Mata (1998). They estimated earning functions for Portugal over the period 1982-94. The focus of study was the evaluation of returns to education and their relation in increasing earning inequality. The results confirmed that returns to secondary and college education increased at all quantiles of the earning distribution during the period under study. Moreover, the difference in returns at upper and lower quantiles had widened and earning inequality due to education had increased during the period. On the same line, Hartog et al. (2001) verified the relationship of returns to education and earning inequality over the period 1982-92 for Portugal. Budria and Egido (2005) found the relation of schooling and earning inequality for the period 1994-2001 in Spain. They found that higher education was related with higher earning inequality. Fiszbein and Patrinos (2005) estimated returns to education in urban Argentina for period 1992-2002. The results showed that men at higher quantiles had higher returns compared to those at the lower quantiles. For women returns were highest at the lowest quantiles. In addition, earning inequality due to education among men and women had increased during the period. Stefani and Biderman (2006) analyzed the returns to education across the conditional earning distribution using quantile regression method for Brazil. It was found that the returns to education were significantly different across the distribution of earnings. Chunbing (2007) estimated earning equations of different ownerships in China using quantile regression technique. The returns to schooling were greater at lower quantiles of earning distribution in 1991 and 1993 but not in 1997 for state-owned enterprises. For the private sector, returns were larger at higher quantiles of earning distribution in 1993 and 1997. Budria (2010) used data from Finland, France, Germany, Italy, Norway, Portugal, Sweden and UK to explain the impact of education on wage distribution in private and public sector by using quantile regression. The results of the study indicated that the impact of education on different parts of wage distribution was significantly different in each sector for these countries.

\section{Methodology}

The quantile regression method was introduced by Koenker and Basset (1978). Quantile regression (QR) specifies the relationship between explanatory variables and a particular quantiles (or percentiles) of the dependent variable. A complete picture of the effect of the explanatory variable on all parts of the dependent variable can be obtained by using this method. Estimates of QR are similarly interpreted as OLS regression estimates; they indicate the influence of explanatory variables on the $\theta$ th quantile of the dependent variable. Following Buchinsky (1998), the quantile regression earning function can be written as follows:

$$
\operatorname{Lnw}_{i}=x_{i} \beta_{\theta}+u_{\theta i} \text { with } \operatorname{Quant}_{\theta}\left(\operatorname{Lnw}_{i} \mid x_{i}\right)=x_{i} \beta_{\theta}
$$

Where $x$ is the vector of explanatory variables and $\beta$ is the vector of parameters and $u_{\theta}$ is random error term. Quant $_{\boldsymbol{\theta}}\left(\boldsymbol{L n}_{\boldsymbol{i}} \mid \boldsymbol{x}_{\boldsymbol{i}}\right)$ denotes the $\theta$ th conditional quantile of $\ln w$, given $x_{\mathrm{i}}$. Unlike in OLS, quantile regression parameters minimize the absolute sum of the errors from a particular quantile of the log earnings. The $\theta$ th quantile regression, $0<\theta<1$, is defined as a solution to the problem:

$$
\min \left[\sum_{i: L n w_{i} \geq x \beta} \theta\left|L n w_{i}-x_{i} \beta_{\theta}\right|+\sum_{i: L n w_{i}<x \beta}(1-\theta)\left|L n w_{i}-x_{i} \beta_{\theta}\right|\right]
$$

By variation of $\boldsymbol{\theta}$, any quantile of the conditional distribution can be obtained. We use $\boldsymbol{\beta}_{\boldsymbol{\theta}}$ instead of $\boldsymbol{\beta}$ to make clear that different values of $\boldsymbol{\theta}$ give different values of $\beta$. For the minimization of problem, linear programming techniques are utilized to solve the problem by using complete sample. Robust standard errors for vector of coefficients are obtained by using bootstrapping procedure.

Empirical Specification of Model: The empirical earning function is specified as follows:

$$
L n w_{i}=\alpha+\beta_{\theta 1} \text { primary }+\beta_{\theta 2} \sec \text { ondary }+\beta_{\theta 3} \text { tertiary }+\sum_{i} \delta_{\theta i} Z_{i}+u_{\theta i}
$$


Where, $\Theta$ is quantile being analyzed, $\mathbf{L n w}$ is the natural log of monthly earnings for the ith individual. Primary, secondary and tertiary refer to dummy variables for primary, secondary and tertiary education. Primary is equal to 1 if individual has education from 1 to 5 years of schooling and zero otherwise. Secondary is equal to 1 if individual has education from 6 to 12 years of schooling and zero otherwise while tertiary is equal to 1 if individual has education higher than 12 years of schooling (or higher than secondary education) and zero otherwise. No education is omitted category. $Z$ includes labor market experience, square of labor market experience, dummies for gender, marital status, region of residence, occupation and province of residence. The above specified earning model is estimated at nine deciles of conditional earnings distribution. The standard errors of estimates are obtained by bootstrapping with 100 repetitions. The study uses Pakistan Social and Living Standards Measurement (PSLM) Survey data for the period 2005-06 and 2007-08. Keeping in the view the standard definition of labor force, only individuals ranging from age 15 to 65 are kept in the samples.

\section{Results and Discussion}

The specified earning function has been estimated at nine deciles for each of the two years. Only coefficients of primary, secondary and tertiary dummies in the earning function and their respective t-statistics are presented in Table 1. These results show that effect of each level of education on earnings is positive and statistically significant at each of the deciles analyzed for both of the years. Returns to each level of education are not equal at each decile. In other words, each level of education has a different effect on earnings across earning distribution.

Table 1: Estimated Coefficients on Primary, Secondary and Tertiary Education Dummies for 2005-06 and 2007-08

\begin{tabular}{lllllll}
\hline & Primary & & \multicolumn{3}{c}{ Secondary } & \multicolumn{3}{c}{ Tertiary } \\
\hline Deciles & $\mathbf{2 0 0 5}$ & $\mathbf{2 0 0 7}$ & $\mathbf{2 0 0 5}$ & $\mathbf{2 0 0 7}$ & $\mathbf{2 0 0 5}$ & $\mathbf{2 0 0 7}$ \\
\hline$\Theta=0.1$ & $0.133^{*}$ & $0.147^{*}$ & $0.384^{*}$ & $0.379^{*}$ & $0.800^{*}$ & $0.802^{*}$ \\
& $(5.27)$ & $(5.46)$ & $(13.12)$ & $(18.75)$ & $(21.45)$ & $(23.46)$ \\
$\Theta=0.2$ & $0.135^{*}$ & $0.172^{*}$ & $0.364^{*}$ & $0.423^{*}$ & $0.830^{*}$ & $0.855^{*}$ \\
& $(9.30)$ & $(9.74)$ & $(18.05)$ & $(28.78)$ & $(29.43)$ & $(34.16)$ \\
$\Theta=0.3$ & $0.151^{*}$ & $0.188^{*}$ & $0.390^{*}$ & $0.442^{*}$ & $0.860^{*}$ & $0.858^{*}$ \\
& $(11.02)$ & $(12.70)$ & $(23.33)$ & $(35.95)$ & $(35.54)$ & $(46.12)$ \\
$\Theta=0.4$ & $0.151^{*}$ & $0.191^{*}$ & $0.397^{*}$ & $0.452^{*}$ & $0.895^{*}$ & $0.875^{*}$ \\
& $(12.15)$ & $(12.05)$ & $(26.90)$ & $(41.12)$ & $(30.10)$ & $(41.70)$ \\
$\Theta=0.5$ & $0.165^{*}$ & $0.209^{*}$ & $0.423^{*}$ & $0.471^{*}$ & $0.920^{*}$ & $0.924^{*}$ \\
& $(15.32)$ & $(16.33)$ & $(31.15)$ & $(46.56)$ & $(35.82)$ & $(49.57)$ \\
$\Theta=0.6$ & $0.187^{*}$ & $0.222^{*}$ & $0.454^{*}$ & $0.492^{*}$ & $0.983^{*}$ & $0.978^{*}$ \\
& $(17.04)$ & $(13.85)$ & $(39.88)$ & $(40.71)$ & $(43.89)$ & $(50.18)$ \\
$\Theta=0.7$ & $0.194^{*}$ & $0.221^{*}$ & $0.485^{*}$ & $0.507^{*}$ & $1.030^{*}$ & $1.014^{*}$ \\
& $(17.74)$ & $(16.08)$ & $(34.33)$ & $(47.61)$ & $(30.97)$ & $(36.21)$ \\
$\Theta=0.8$ & $0.192^{*}$ & $0.235^{*}$ & $0.519^{*}$ & $0.542^{*}$ & $1.087^{*}$ & $1.073^{*}$ \\
& $(12.46)$ & $(14.12)$ & $(31.98)$ & $(35.52)$ & $(37.41)$ & $(41.04)$ \\
$\Theta=0.9$ & $0.219^{*}$ & $0.257^{*}$ & $0.600^{*}$ & $0.564^{*}$ & $1.220^{*}$ & $1.142^{*}$ \\
& $(13.79)$ & $(12.47)$ & $(19.84)$ & $(25.37)$ & $(30.17)$ & $(29.76)$ \\
OLS & $0.175^{*}$ & $0.220^{*}$ & $0.466^{*}$ & $0.519^{*}$ & $0.996^{*}$ & $1.014^{*}$ \\
& $(12.74)$ & $(16.74)$ & $(35.75)$ & $(42.36)$ & $(46.20)$ & $(49.53)$ \\
\hline
\end{tabular}

Note: t-statistics are in parentheses; * significant at $1 \%$

It reveals that effect of each level of education on earning increases as we move from lower to upper quantiles of the earnings distribution. It implies that there is heterogeneity in returns to each level of education. However, this heterogeneity in returns for primary and secondary education is less as compared to tertiary education. The results show that effect of education at upper tail of earning distribution is higher than at the lower tail of earning distribution in the two years. Therefore, we can conclude that education is a factor which promotes within group earning inequality. The changes in the returns to education for different levels of education over time can also be observed from the table. For primary education, there is an increase in 
returns at all deciles during 2005-07. The returns to secondary education have increased at almost all deciles except at 0.1 decile during the period under study. For the period 2005-07, returns to tertiary education are higher in 2007 than in 2005 until 0.3 decile while returns are identical at median of the distribution in 2005 and 2007. However, higher returns are obvious after 0.6 deciles in 2005 over 2007. This implies that returns to tertiary education have decreased at upper part of the earning distribution during 2005-07. This may be attributed to increase in supply of university graduates in labor market during this period. These results follows the findings of previous studies (e.g. Hartog et al., 2001: Patrinos and Sakellariou, 2006; Fiszbein and Patrinos, 2005; Fersterer and Winter-Ebmer, 2003; Gonzalez and Miles, 2001). Furthermore, in both the years, returns to education are convex that is, effect of education on earnings tends to increase as the level of education increases. These returns are higher for tertiary education as compared to primary and secondary levels across all quantiles of earnings distribution. The pattern of higher returns as level of education becomes higher is also obvious by the OLS results. This confirms that education also causes earning inequality between different educational groups.

\section{Conclusion}

The study analyzes the role of education in raising earning inequality in Pakistan over the period 2005-07. This issue has not received much attention so far in the literature on earning inequality. By employing quantile regression method, the results show that the effect of each level of education at upper tail of earning distribution is higher than at lower tail of earning distribution. Moreover, returns to education for different levels of education have changed during the period under study. Based on the econometric findings, we conclude that education is a factor which promotes within group earning inequality. In addition, returns to education are convex which confirm that education also causes earning inequality between educational groups. The results of study unveils that goal of fair income distribution through education is conflicting, that is, it rings alarm bells for policy design which based on the ground that investing in education reduces earnings inequality.

\section{References}

Becker, G. S. (1993). Human Capital: A Theoretical and Empirical Analysis, with Special Reference to Education. Chicago: University of Chicago Press.

Buchinsky, M. (1994). Changes in the US Wage Structure 1963-1987: Application of Quantile Regression. Econometrica, 62, 405-458.

Buchinsky, M. (1998). The Dynamic of Changes in the Female Wage Distribution in the US: A Quantile Regression Approach. Journal of Applied Econometrics, 13, 1-30.

Budría, S. \& Egido, A. M. (2005). Education, Educational Mismatch and Wage Inequality: Evidence for Spain. Working Paper No. 06, University of Madeira.

Budría, S. (2010). Schooling and the Distribution of Wages in the European Private and Public Sectors. Applied Economics, 42, 1045-1054.

Checchi, D. (2003). Inequality in Incomes and Access to Education: A Cross-country Analysis (1960-95). Labour, 17, 153-201.

Chunbing, X. (2007). Wage Determination and Returns to Education in Different Ownerships of China: Evidence from Quantile Regressions. Front. Econ. China, 2, 114-136.

Fersterer, J. \& Winter-Ebmer, R. (2003). Are Austrian Returns to Education Falling Over time? Labour Economics, 10, 73-89.

Fiszbein, A. \& Patrinos, H. (2005). Estimating the Returns to Education in Argentina: 1992-2002. Working Paper No. 3715, World Bank.

Gonzalez, X. \& Miles, D. (2001). Wage Inequality in a Developing Country: Decrease in Minimum Wage or Increase in Education Returns. Empirical Economics, 26, 135-148.

Gregorio, J. D. \& Lee, J. (2002). Education and Income Inequality: New Evidence from Cross-Country Data. Review of Income and Wealth, 48, 395-416.

Hartog, J., Pereira, P. T. \& Vieira, A. C. (2001). Changing Returns to Education in Portugal during the 1980s and Early 1990s: OLS and Quantile Regression Estimators. Applied Economics, 33, 1021-1037.

Koenker, R. \& Bassett, G. (1978). Regression Quantiles. Econometrica, 46, 33-50

Kuznets, S. (1955). Economic Growth and Income Inequality. American Economic Review, 45, 1-28. 
Machado, J. A. \& Mata, J. (1998). Earning functions in Portugal 1982-1994: Evidence from quantile regressions. Working Paper No. 2, Bank of Portugal Lisbon.

Machado, J. A. \& Mata, J. (2001). Earning Functions in Portugal 1982-1994: Evidence from Quantile Regressions. Empirical Economics, 26, 115-134.

Patrinos, H. A. \& Sakellariou, C. (2006). Economic Volatility and Returns to Education in Venezuela: 19922002. Applied Economics, 38, 1991-2005.

Stefani, P. \& Biderman, C. (2006). Returns to Education and Wage Differentials in Brazil: A Quantile Regression Approach. Economics Bulletin, 9, 1-6.

Sylwester, K. (2002). Can Education Expenditures Reduce Income Inequality? Economics of Education Review, 21, 43-52. 